\title{
Simulation of a wastewater treatment plant receiving industrial effluents"
}

\author{
FT Mhlanga1 ${ }^{1}$ CJ Brouckaert ${ }^{1 *}$, KM Foxon ${ }^{1}$, C Fennemore ${ }^{2}$, D Mzulwini ${ }^{1}$ and CA Buckley ${ }^{1}$ \\ ${ }^{1}$ Pollution Research Group, School of Chemical Engineering, University of KwaZulu-Natal, Durban 4041, South Africa \\ ${ }^{2}$ eThekwini Water Services, 3 Prior Road, Durban 4041, South Africa
}

\begin{abstract}
A process model simulating the Mariannridge Wastewater Treatment Plant, located in the eThekwini Municipality, has been developed in the WEST (Worldwide Engine for Simulation, Training and Automation) modelling environment, based on the IWA Activated Sludge Model No. 3 (ASM3). The treatment plant receives a high proportion of industrial effluents. The development of the model involves the characterisation of the influent wastewater and determining model parameters (kinetic and stoichiometric coefficients) by undertaking batch respirometric tests on the wastewater and activated sludge, flocculation filtration and simulation of the batch respirometric experiment. To account for equipment-specific factors, the simulation model was calibrated against plant data covering a year's operation.

The model is intended to be used as part of a system to evaluate the ability of a receiving wastewater treatment works to adequately treat a particular industrial effluent before granting a permit for it to be discharged to sewer.
\end{abstract}

Keywords: oxygen uptake rate, activated sludge process, calibration

\section{List of abbreviations}

ASM3

ASU

COD

DO

IWA

OUR

SS

TKN

TP

TSS

UCT

VSS

WEST

WRC

WWTP
Activated Sludge Model Number 3

Activated sludge unit

Chemical oxygen demand

Dissolved oxygen

International Water Association

Oxygen uptake rate

Suspended solids

Total Kjeldahl nitrogen

Total phosphorus

Total suspended solids

University of Cape Town

Volatile suspended solids

Worldwide Engine for Simulation, Training and Automation

Water Research Commission of South Africa Wastewater treatment plant

\section{List of symbols}

$\mathrm{b}_{\mathrm{A}} \quad$ Decay rate constant of autotrophs (/d)

$\mathrm{b}_{\mathrm{H}} \quad$ Decay rate constant of heterotrophs (/d)

$\mathrm{C}_{\mathrm{TCOD}}$ Total COD $\left(\mathrm{gCOD} / \mathrm{m}^{3}\right)$

$\mathrm{f}_{\mathrm{ns}} \quad$ Non-settleable fraction of suspended solids (-)

$\mathrm{K}_{\mathrm{A}_{-} \mathrm{NH}}$ Ammonium saturation constant for autotrophs $\left(\mathrm{gN} / \mathrm{m}^{3}\right)$

$\mathrm{K}_{\mathrm{A} \_\mathrm{O}}$ Oxygen saturation constant for autotrophs $\left(\mathrm{gO}_{2} / \mathrm{m}^{3}\right)$

$\mathrm{k}_{\mathrm{h}} \quad$ Hydrolysis rate constant $\left(\mathrm{gCOD}_{\mathrm{Xs}} / \mathrm{gCOD}_{\mathrm{XH}}\right)$

$\mathrm{K}_{\mathrm{NH}} \quad$ Saturation constant for ammonium $\left(\mathrm{gN} / \mathrm{m}^{3}\right)$

$\mathrm{K}_{\mathrm{O}}^{\mathrm{NH}} \quad$ Oxygen saturation constant for heterotrophs $\left(\mathrm{gO}_{2} / \mathrm{m}^{3}\right)$

\# Revised version. Paper originally presented at the WISA 2008 Conference, 18-22 May 2008, Sun City, South Africa.

* To whom all correspondence should be addressed.

용 +2731260 1129/3375; fax: +2731 $2603241 / 1118$; e-mail: brouckae@ukzn.ac.za

Received 12 September 2008; accepted in revised form 31 March 2009.
$\mathrm{K}_{\mathrm{S}} \quad$ Saturation constant for $\mathrm{S}_{\mathrm{S}}\left(\mathrm{gCOD}_{\mathrm{Ss}} / \mathrm{m}^{3}\right)$

$\mathrm{K}_{\mathrm{X}} \quad$ Saturation constant for particulate COD $\left(\mathrm{gCOD}_{\mathrm{xs}} / \mathrm{gCOD}_{\mathrm{XH}}\right)$

$\mathrm{S}_{\mathrm{I}} \quad$ Soluble inert organics $\left(\mathrm{gCOD} / \mathrm{m}^{3}\right)$

$\mathrm{S}_{\mathrm{S}} \quad$ Readily biodegradable substrate $\left(\mathrm{gCOD} / \mathrm{m}^{3}\right)$

$\mathrm{X}_{\mathrm{A}} \quad$ Autotrophic, nitrifying biomass $\left(\mathrm{gCOD} / \mathrm{m}^{3}\right)$

$\mathrm{X}_{\mathrm{H}} \quad$ Heterotrophic biomass $\left(\mathrm{gCOD} / \mathrm{m}^{3}\right)$

$\mathrm{X}_{\mathrm{I}} \quad$ Inert, particulate organics $\left(\mathrm{gCOD} / \mathrm{m}^{3}\right)$

$\mathrm{X}_{\mathrm{S}} \quad$ Slowly biodegradable substrate $\left(\mathrm{gCOD} / \mathrm{m}^{3}\right)$

$\mathrm{X}_{\text {STO }}$ Organics stored by heterotrophs $\left(\mathrm{gCOD} / \mathrm{m}^{3}\right)$

$\mathrm{Y}_{\mathrm{H}} \quad$ Yield coefficient of heterotrophs $\mathrm{gCOD}_{\mathrm{xH}} / \mathrm{gCOD}_{\mathrm{XSTO}}$

$\mu_{\mathrm{A}} \quad$ Maximum growth rate of autotrophs (/d)

$\mu_{\mathrm{H}} \quad$ Maximum growth rate of heterotrophs (/d)

\section{Introduction}

The key elements available to a municipality for the management of industrial wastewater are wastewater treatment plants for remediation, discharge permits for placing limits on what may be discharged, and discharge tariffs for financing the treatment and for providing incentives and penalties for the users of the system. An optimal strategy for managing industrial wastewater should include all these elements to serve the users of the sewer system, while meeting the discharge standards for the treated effluent. However the relationship between these elements is complex and poorly understood because of the variable nature of effluents discharged from industries and the response of the biological processes to them. In response to this challenge, the eThekwini Municipality motivated a research project to develop a means of determining the link between a permitted industrial discharge and the capacity of the receiving WWTP to treat it to meet the river discharge standards imposed by the Department of Water Affairs and Forestry for the given WWTP.

Developing a simulation model for a wastewater treatment plant and calibrating it against plant operating data allows the response of the wastewater treatment plant to a particular wastewater to be evaluated. Hence modelling of biological wastewater treatment systems can be used as a tool for evaluation. For this application, the model needs to be able to 
represent the performance of the WWTP while treating the combined influent received from its catchment. Typically this will include domestic sewage together with the industrial effluent generated by all the factories in the catchment. To avoid having to individually characterise effluents from all the other factories in order to evaluate the effect of the one of interest, the baseline model is based on experimental characterisation of the combined feed to the WWTP.

The modelling of biological wastewater treatment systems has developed from fundamental concepts to mathematical models. The IAWPRC, later IAWQ and now IWA task Group (Henze et al., 1987, 2000) has introduced an activated sludge model suite, which provides researchers and practitioners with a standard set of basic models for biological wastewater treatment processes. The first model developed for municipal activated sludge WWTPs was the Activated Sludge Model No. 1 (ASM1) (Henze et al., 1987). It describes the removal of organic carbon compounds and ammonia-nitrogen, with facultative consumption of oxygen or nitrate as the electron acceptor, depending on the conditions in the activated sludge system. Other models, ASM2 (Henze et al., 1995) and ASM2d (Henze et al., 1999), which include chemical precipitation processes and phosphorus removal, have also been developed. To correct a number of shortcomings of the ASM1 model, the ASM3 model (Gujer et al., 1999) was developed based on the ASM1 model. ASM3 was used to model the Mariannridge WWTP.

This paper presents the development of such a baseline model based on ASM3, for a WWTP receiving a significant proportion of industrial effluent, based on a combination of laboratory tests and plant operating data.

\section{Materials and methods}

\section{Site description and layout}

The Mariannridge WWTP has a sister plant on the same site called Shallcross WWTP. These 2 parallel plants make up what is known as the Umhlatuzana Works. Mariannridge receives an average of $8000 \mathrm{~m}^{3} / \mathrm{d}$ wastewater of which about $30 \%$ is industrial and $70 \%$ domestic, while Shallcross receives an average of $2000 \mathrm{~m}^{3} / \mathrm{d}$ which is entirely domestic wastewater. The layout of Mariannridge WWTP is shown in Fig. 1.

Influent is pumped into an equalisation tank, and then screened before going through the grit chambers. From the grit chambers the flow rate is measured before the biological reactor (an extended aeration basin), which is followed by secondary clarification in settling tanks. The effluent from the Mariannridge WWTP is combined with the effluent from Shallcross WWTP and dosed with chlorine before releasing it to the Umhlatuzana River.

\section{Influent characterisation}

The mathematical models developed for the simulation of the activated sludge unit of the WWTP are based on the division of wastewater into various fractions (Sperandio et al., 2000). The carbonaceous fraction of wastewater is determined by the COD test. In the ASM3 model the total influent COD of municipal wastewater is divided into 7 fractions, as shown in Table 1.

\begin{tabular}{|l|l|}
\hline \multicolumn{2}{|c|}{ TABLE 1 } \\
COD fractionation according to ASM3 \\
\hline Symbol & Component \\
\hline$S_{S}$ & Readily biodegradable substrate \\
\hline$S_{\mathrm{I}}$ & Soluble inert organics \\
\hline$X_{\mathrm{I}}$ & Inert, particulate organics \\
\hline$X_{\mathrm{S}}$ & Slowly biodegradable substrate \\
\hline $\mathrm{X}_{\mathrm{H}}$ & Heterotrophic biomass \\
\hline $\mathrm{X}_{\mathrm{A}}$ & Autotrophic, nitrifying biomass \\
\hline $\mathrm{X}_{\text {STO }}$ & Organics stored by heterotrophs \\
\hline
\end{tabular}

The concentration of autotrophic biomass, $\mathrm{X}_{\mathrm{A}}$, in the influent is in most cases negligible (Henze et al., 1995). The organics stored by heterotrophs, $\mathrm{X}_{\text {Сто, }}$ is not considered to be present in the influent wastewater but it is only a functional compound required for modelling, not directly identifiable by chemical analysis (Gujer et al., 1999). Consequently, the influent total COD is then represented by Eq. (1).

$$
\mathrm{C}_{\mathrm{TCOD}}=\mathrm{S}_{\mathrm{S}}+\mathrm{S}_{\mathrm{I}}+\mathrm{X}_{\mathrm{I}}+\mathrm{X}_{\mathrm{S}}+\mathrm{X}_{\mathrm{H}}
$$

The available procedures for quantifying the COD fractions in municipal wastewater are either physical or biologically based. Biologically based tests (bioassays) have found wider application than physical tests (Wentzel et al., 1995). Physical methods have been developed to quantify readily biodegradable substrate $\mathrm{S}_{\mathrm{S}}$ based on the hypothesis that the difference in biokinetic response of activated sludge to readily biodegradable substrate and slowly biodegradable substrate $\mathrm{X}_{\mathrm{S}}$ is due to the difference in molecular size - readily biodegradable substrate consists of relatively smaller molecules which are readily transported into microbial cells while slowly biodegradable substrate contains larger and more complex molecules which require hydrolysis before uptake and utilisation (Dold et al., $1980 ; 1986)$. Based on this hypothesis filtration procedures have been proposed for the separation of the 2 COD fractions (Dold et al., 1986; Lesouef et al., 1992; Mamais et., al 1993; Bortone et al., 1994; Torrijos et al., 1994). The success of filtration procedures has been closely linked to the filter pore size, where the larger the pore size, the more particulate material passes through the filter resulting in a less accurate

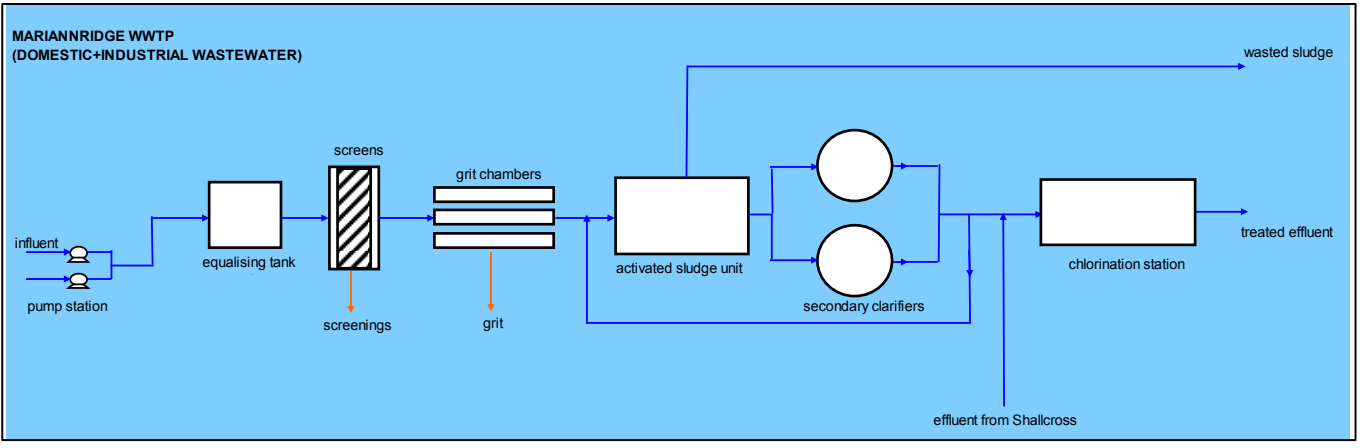

Figure 1 
Figure 2

Schematic layout of the OUR meter and the completely mixed biological batch reactor

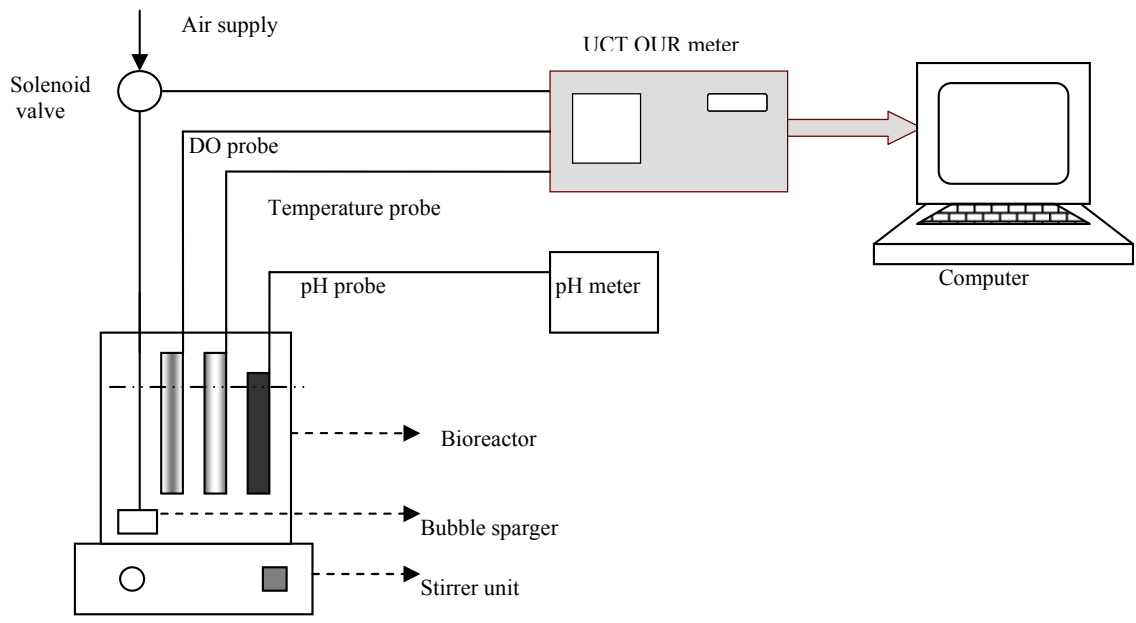

separation of readily biodegradable substrate from slowly biodegradable substrate (Wentzel et al., 1995). Furthermore, in activated sludge models the division of the influent COD in municipal wastewater is based on biological response in which the response of activated sludge to wastewater is monitored, rather than the difference in molecular size, hence the use of a batch respirometric test in this study to determine the readily biodegradable substrate $S_{S}$ and heterotrophic biomass $X_{H}$ in the influent wastewater using batch respirometric experiments outlined by Wentzel et al. (1995). The diagram of the respirometric experiment is shown in Fig. 2.

The experiment was carried out in a $3 \ell$ cylindrical aerated bioreactor. A magnetic stirrer was used to stir the contents of the bioreactor. Batches of unsettled $24 \mathrm{~h}$ composite samples of influent wastewater were obtained from the WWTP from the inlet after the screens but before the aeration basin. A defined volume of $2 \ell$ was placed in the continually stirred bioreactor. An aliquot of the composite sample was drawn and the initial total influent COD concentration was determined as outlined in Standard Methods (1995). The OUR was monitored continually using the automated UCT OUR meter. The $\mathrm{pH}$ and temperature were monitored and maintained at constant values of 7.2 and $20^{\circ} \mathrm{C}$. OUR values measured at increased variations in temperature were adjusted accordingly by temperature correction. A second stage in the respirometric experiments, based on the work by Hvitved-Jacobsen et al. (2002) where acetate is added, was incorporated into the experiment to investigate the growth of biomass. A typical OUR-curve plotted from the complete batch respirometric experiment is shown in Fig. 3.

The OUR curve is divided into 4 phases based on the substrate concentrations in the wastewater sample as shown in Fig. 2.

- Substrate non-limited condition

- Substrate non-limited condition is being terminated

- Substrate limited condition

- Addition of readily biodegradable substrate

The OUR data from the first stage of the batch test before the addition of readily biodegradable substrate (sodium acetate) were interpreted using the UCT (Dold et al., 1980) and IWA models to determine $\mathrm{S}_{\mathrm{S}}$ and $\mathrm{X}_{\mathrm{H}}$. The selected models describe the bacterial degradation dynamics which take place during the bioassay test in which the measured variable is DO concentration (Lagarde et al., 2003).

After running the batch respirometric test for $24 \mathrm{~h}$, the only soluble COD remaining should be non-biodegradable.

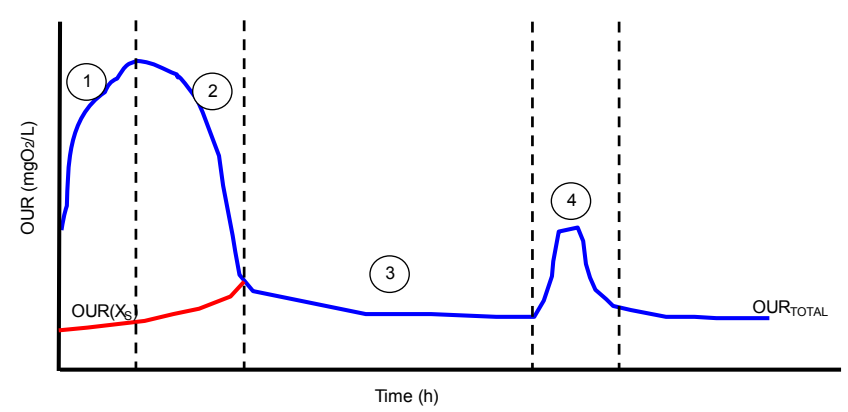

Figure 3

OUR-curve for influent wastewater with addition of readily biodegradable substrate

Therefore, at the end of the batch test, a sample is drawn from the reactor contents to determine the inert soluble substrate $S_{I}$ through a flocculation-filtration procedure.

In the batch test, it is impossible to differentiate between inert particulate substrate and slowly biodegradable substrate by direct measurement. Furthermore, physical separation technique, such as flocculation filtration cannot separate the 2 COD fractions, since both are particulate. The inert particulate substrate $\mathrm{X}_{\mathrm{I}}$ is determined from the simulation model of the batch respirometric experiment. With 4 COD fractions known, the slowly biodegradable substrate $\mathrm{X}_{\mathrm{S}}$ is determined by difference, using Eq. (1).

The nitrogen, phosphorus and other constituent fractions of the influent wastewater at Mariannridge Plant were obtained from historical data collected by the municipal laboratory from wastewater samples taken from the WWTP. The data used were for the years 2005, 2006 and 2007 and they are summarised in Table 2 (next page).

\section{Modelling tools}

The scope of the modelling included the activated sludge unit and the secondary settlers. Model simulations were performed using the software package WEST (MOSTforWATER, 2004).

Several models of activated sludge processes are available. The most widely used are the IWA activated sludge models. The IWA Activated Sludge Model No. 3 (ASM3) (Gujer et al., 1999) was chosen as the basis for the Mariannridge Plant model. This model relates the wastewater treatment processes to the oxygen consumption, sludge production, nitrification and de-nitrification 


\begin{tabular}{|l|c|c|c|c|c|}
\hline \multicolumn{7}{|c|}{ TABLE 2 } \\
\hline Historical data of the influent composition - Mariannridge WWTP \\
\hline Component & Average & Minimum & Maximum & Units & No. of samples \\
\hline Total COD & 774 & 105 & 2700 & $\mathrm{mg} \mathrm{O} / \ell$ & 291 \\
\hline Total Kjeldahl nitrogen & 55 & 11 & 80 & $\mathrm{mg} \mathrm{N} / \ell$ & 15 \\
\hline Free ammonia & 25 & 1 & 82 & $\mathrm{mg} \mathrm{N} / \ell$ & 325 \\
\hline Nitrate & 0.8 & 0.4 & 1.6 & $\mathrm{mg} \mathrm{N} / \ell$ & 15 \\
\hline Total phosphate & 8 & 6 & 15 & $\mathrm{mg} \mathrm{P} / \ell$ & 113 \\
\hline Orthophosphate & 9 & 1 & 12 & $\mathrm{mg} \mathrm{P} / \ell$ & 15 \\
\hline Settleable solids & 18 & 2 & 100 & $\mathrm{mg} / \ell$ & 81 \\
\hline Suspended solids & 300 & 21 & 1592 & $\mathrm{mg} / \ell$ & 62 \\
\hline Total dissolved solids & 570 & 212 & 934 & $\mathrm{mg} / \ell$ & 19 \\
\hline Total solids & 1095 & 320 & 2426 & $\mathrm{mg} / \ell$ & 48 \\
\hline
\end{tabular}

which take place in activated sludge systems during the treatment of wastewater of primary domestic origin. ASM3 uses the concept of storage-mediated growth of heterotrophic organisms assuming that all readily biodegradable substrate is first taken up and stored in an internal polymer component.

Several different settler models exist in literature, as discussed by Grijspeerdt et al. (1995). However, the plant data used in this study were taken from routine operating records which did not contain information on operation of the settlers. The only available information related to the settlers was the SS concentration in the combined final effluent leaving the plant. Consequently a simple representation of the settling process could be used. The point settler model, which simply specifies the clarified effluent suspended solids, was used to represent the secondary settlers.

\section{Modelling information}

In general, the required quality and quantity of information will depend on the purpose of the model (Langergraber et al., 2004;
Sin et al., 2005). For this study the presence of industrial effluent in the plant influent and the intended purpose of this model (i.e. to evaluate the effect of industrial effluent on the performance of the treatment plant) required that the model be specifically adapted to conditions prevailing at the WWTP. The set of information which needs to be collected for successful modelling is summarised from different sources (Henze et al., 1987; Lesouef et al., 1992; Pedersen and Sinkjaer, 1992; Stokes et al., 1993) in Table 3.

Design and operational data were obtained from the plant records of the Mariannridge Plant. The flow balance of the Mariannridge WWTP based on the average influent of $8000 \mathrm{~m}^{3} / \mathrm{d}$ at the head of the works and a recycle stream of $17280 \mathrm{~m}^{3} / \mathrm{d}$ is shown in Fig. 4. The effluent from Mariannridge WWTP is combined with $1600 \mathrm{~m}^{3} / \mathrm{d}$ effluent coming from the Shallcross WWTP. The volume of the activated sludge unit is $13600 \mathrm{~m}^{3}$ and it contains 8 aerators each of which deliver $100 \mathrm{~kg} \mathrm{O}_{2} / \mathrm{h}$. Only 4 aerators run at a time. The volume of the 2 secondary clarifiers is $2037 \mathrm{~m}^{3}$.

For the characterisation of the setter model, TSS measurements were available for the final combined effluent from both
Figure 4

Flow balance of the Mariannridge WWTP

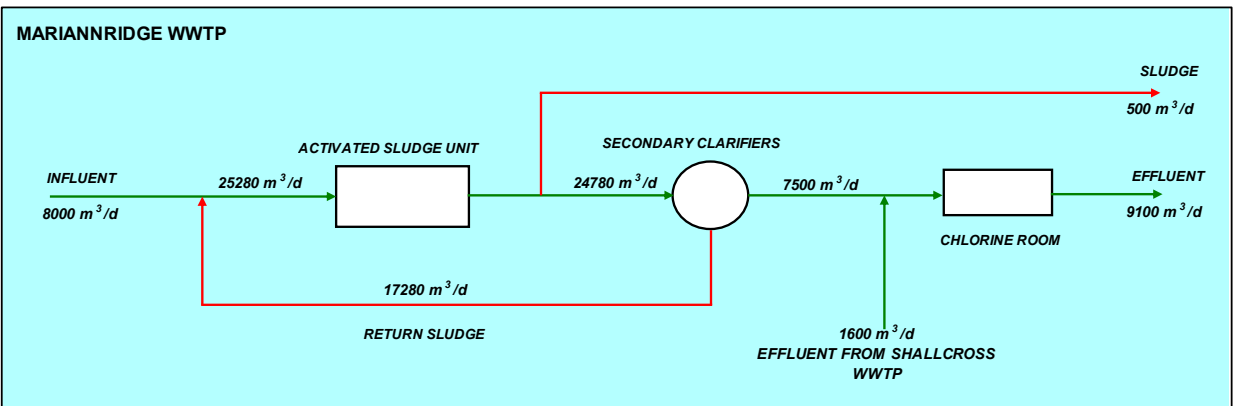

TABLE 3

Summary of information required for successful modelling

\section{Category}

Design data and operational data Characterisation for the settler model

Characterisation for the activated sludge model

\section{Information}

Reactor volumes, pump flows and aeration capacities, flow rates (average or dynamic trajectories) of influent, effluent, recycle flow rate, $\mathrm{pH}$, aeration and temperature

Zone settling velocities at different mixed liquor suspended solids concentrations, particulate fraction in effluent Wastewater concentrations of the influent and effluent as well as some intermediate streams between the WWTP unit processes, as averages or as dynamic trajectories (e.g. $\mathrm{SS}, \mathrm{COD}, \mathrm{TKN}, \mathrm{NH}_{4}-\mathrm{N}, \mathrm{NO}_{3}-\mathrm{N}, \mathrm{PO}_{4}-\mathrm{P}$, etc.)

Sludge compositions (e.g. SS, VSS, COD, N and P content)

Reaction kinetics (e.g. growth and decay rates)

Reaction stoichiometry (e.g. biomass yields) 


\begin{tabular}{|c|c|c|c|}
\hline \multicolumn{4}{|c|}{$\begin{array}{c}\text { TABLE } 4 \\
\text { COD fractions of the Mariannridge influent wastewater compared to } \\
\text { typical South African wastewater }\end{array}$} \\
\hline \multirow[t]{2}{*}{ Symbol } & \multirow[t]{2}{*}{ Description } & \multicolumn{2}{|c|}{$\%$ of Total COD in influent wastewater } \\
\hline & & Mariannridge & SA wastewater \\
\hline $\mathrm{S}_{\mathrm{I}}$ & Soluble inert organics & 7.5 & 7 \\
\hline $\mathrm{S}_{\mathrm{S}}$ & Readily biodegradable substrate & 18.1 & 20 \\
\hline $\mathrm{X}_{\mathrm{S}}$ & Slowly biodegradable substrate & 44.2 & 60 \\
\hline $\mathrm{X}_{\mathrm{I}}$ & Inert particulate organics & 15.6 & 13 \\
\hline $\mathrm{X}_{\mathrm{H}}$ & Heterotrophic biomass & 14.6 & $*$ \\
\hline
\end{tabular}

\begin{tabular}{|c|c|c|c|c|c|}
\hline \multicolumn{6}{|c|}{$\begin{array}{c}\text { TABLE } 5 \\
\text { Results obtained for model parameters compared with ASM3 default values at } 20^{\circ} \mathrm{C}\end{array}$} \\
\hline Symbol & Description & Unit & Mean & Std. dev. & ASM3 \\
\hline $\mathrm{Y}_{\mathrm{H}}$ & Yield coefficient & $\mathrm{gCOD}_{\mathrm{XH}} / \mathrm{gCOD}_{\mathrm{xSTO}}$ & 0.61 & 0.11 & 0.63 \\
\hline $\mathrm{b}_{\mathrm{H}}$ & Decay rate constant & $\mathrm{d}^{-1}$ & 0.03 & 0.01 & 0.2 \\
\hline$\mu_{\mathrm{H}}$ & Maximum growth rate & $\mathrm{d}^{-1}$ & 2.4 & 0.2 & 2 \\
\hline $\mathrm{k}_{\mathrm{h}}$ & Hydrolysis rate constant & $\mathrm{gCOD}_{\mathrm{XS}} / \mathrm{gCOD}_{\mathrm{XH}}$ & 3.03 & 0.41 & 3 \\
\hline $\mathrm{K}_{\mathrm{S}}$ & Saturation coefficient for $\mathrm{S}_{\mathrm{S}}$ & $\mathrm{gCOD}_{\mathrm{SS}} / \mathrm{m}^{3}$ & 2.31 & 0.26 & 2 \\
\hline $\mathrm{K}_{\mathrm{x}}$ & Saturation coefficient for particulate COD & $\mathrm{gCOD}_{\mathrm{XS}} / \mathrm{gCOD}_{\mathrm{XH}}$ & 1 & - & 1 \\
\hline $\mathrm{K}_{\mathrm{NH}}$ & Saturation coefficient, for $\mathrm{S}_{\mathrm{NH}}$ & $\mathrm{gN} / \mathrm{m}^{3}$ & 0.00107 & 0.0003 & 0.01 \\
\hline $\mathrm{K}_{0}$ & Saturation coefficient. for oxygen & $\mathrm{gO}_{2} / \mathrm{m}^{3}$ & 0.0233 & 0.0367 & 0.2 \\
\hline
\end{tabular}

Mariannridge and Shallcross, but not for the individual effluents. Therefore the TSS in the Mariannridge effluent stream was estimated by assuming that Mariannridge contributes twice as much SS as the Shallcross Plant to the final combined effluent. This estimate was based on spot measurements and the greater volumetric loading of the Mariannridge Plant.

The characterisation for the activated sludge biological model combined some values from literature, historical plant operating data and information from laboratory-scale experiments carried out on samples of wastewater and activated sludge. These are discussed in more detail in the following sections.

\section{Kinetic and stoichiometric parameters}

The values of reaction kinetic and stoichiometric parameters were a combination of default values proposed by Gujer et al., (1999) and values obtained from laboratory experiments by regression. Batch respirometric experiments were carried out on wastewater and activated sludge samples to determine some of the kinetic and stoichiometric parameters of the model and COD fractions.

The saturation coefficient for readily biodegradable substrate, $\mathrm{K}_{\mathrm{S}}$, the saturation coefficient for particulate COD, $\mathrm{K}_{\mathrm{X}}$, and the hydrolysis constant, $\mathrm{k}_{\mathrm{h}}$, were estimated by fitting the OUR results predicted by the simulation model of the batch experiment, to the OUR results which had been recorded in the batch experiment discussed earlier. The curve fitting was done by regression analysis using the WEST software.

To determine the decay rate constant $b_{\mathrm{H}}$, OUR measurements were performed on activated sludge samples in a continuously stirred batch reactor over a period of $24 \mathrm{~h}$. The plot of the natural logarithm of the recorded OUR values vs. time shows an exponential decrease of the biomass as a straight line with the slope, $b_{\mathrm{H}}$.

The aerobic yield of heterotrophic biomass, $\mathrm{Y}_{\mathrm{H}}$ and the heterotrophic maximum growth rate, $\mu_{\mathrm{H}}$ were estimated from the OUR curve plotted from the results obtained from the batch experiment done on $24 \mathrm{~h}$ composite samples of influent wastewater. Table 5 shows the results obtained for the selected model parameters compared to ASM3 default values suggested by Gujer et al. (1999).

\section{Modelling strategy}

The modelling of the WWTP was carried out in 4 steps:

- Creating a configuration for the WWTP in WEST

- Running simulations using the default values and experimentally determined model parameters and evaluating the predictions of the model against measured historical data

- Calibrating the model by systematically adjusting selected model parameters

- Validation of the model using measured historical data which was not used for model calibration.

\section{Results}

The results for the COD fractionation of the influent from the Mariannridge WWTP are compared against the typical fractions of South African wastewater by Ekama and Marais (1984), in Table 4.

The biodegradable COD fractions for the Mariannridge influent are lower than typical values for South African wastewater of domestic origin, as might be expected because of the significant proportion of industrial effluent. The difference between the experimental results and the literature values confirms the need for plant-specific influent characterisation.

\section{The WEST configuration}

The WEST configuration for the Mariannridge WWTP is shown in Fig. 5. 


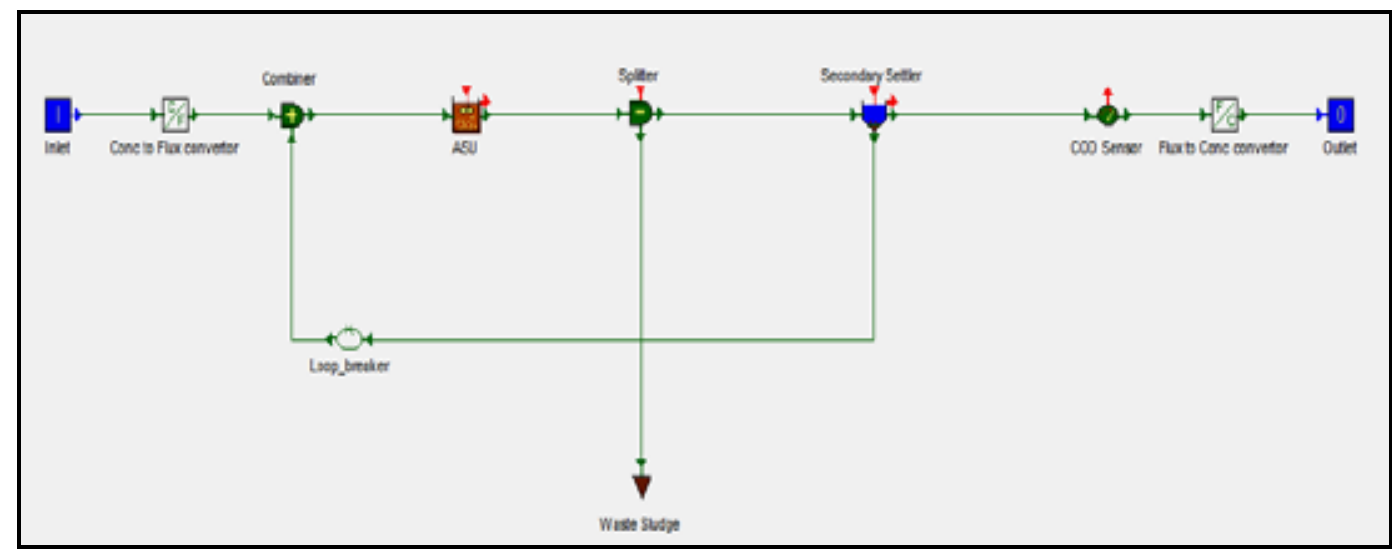

Figure 5

The WEST configuration for the Mariannridge WWTP

The configuration consists of the major units of the WWTP, the ASU and the 2 secondary settlers. The secondary settlers are configured as one unit since it is assumed that they operate in the same way. Combiners and splitters have been added to combine and split flows, respectively. A COD sensor has been added to the outlet stream, to measure the COD concentration of the treated effluent. Convertors in the configuration are used to convert concentrations of constituents in the wastewater to flux values, and flux to concentration values, as required by the following sub-models.

\section{Model calibration}

A major difficulty encountered in calibration of activated sludge models is the lack of identifiability of the model parameters, which is the ability to obtain a unique combination of parameters that fit the calibration data (Petersen et al., 2002). More than one combination of influent characterisation and model parameters can give a description of the available data of similar quality (Gernaey et al., 2004) Due to the identifiability problem a stepwise procedure was used, where just a few parameters are changed at a time instead of applying an automatic mathematical optimisation routine. A steady-state calibration was done followed by a dynamic calibration.

\section{Steady state calibration}

During the steady-state calibration the model parameters responsible for the long-term behaviour of the activated sludge were adjusted to fit the collected plant data for the sludge TSS concentration. Based on the earlier mentioned assumption that the Mariannridge effluent contributes twice as much SS as the
Shallcross WWTP to the final combined effluent TSS concentration, the non-settleable fraction of SS $\mathrm{f}_{\mathrm{ns}}$ was determined from mass balance of SS across the secondary clarifier. The calculated value was 0.0052 .

The measured value of the waste sludge TSS was $456 \mathrm{gSS} / \mathrm{m}^{3}$. The experimentally determined decay rate constant $b_{H}$ was adjusted from $0.03 / \mathrm{d}$ determined from the laboratory batch tests to $0.27 / \mathrm{d}$ (a value close to the default ASM3 value of $0.2 \mathrm{~d}^{-1}$ ), for the model to be able to match the waste sludge TSS concentration.

\section{Dynamic calibration}

During dynamic calibration, selected saturation coefficients and kinetic parameters were adjusted using a mathematical optimisation technique, to improve the prediction of effluent total COD and free ammonia concentration in the activated sludge unit. Before adjusting the selected saturation coefficients and kinetic parameters, a sensitivity analysis was done to establish the most sensitive kinetic or model parameters, which have the most significant impact on the chosen variables of concern, the predicted value of the effluent COD or free ammonia in this study. The values of model parameters determined from the laboratory batch tests are compared with the values adopted after dynamic plant calibration in Table 6 .

\section{Adequacy and reliability of modelling information}

The adequacy and reliability of the information available for the development of the model of the Mariannridge WWTP was evaluated during the calibration of the model to plant operating data. Calibration of the model is the adaptation of the model to fit information obtained from the WWTP. For a given model, if the experimentally determined model parameters do not need

\begin{tabular}{|l|l|l|c|c|}
\hline \multicolumn{5}{|c|}{ TABLE 6 } \\
\hline Symbol & Description & Units & Before calibration & After calibration \\
\hline $\mathrm{Y}_{\mathrm{H}}$ & Yield coefficient & $\mathrm{gCOD}_{\mathrm{XH}} / \mathrm{gCOD}_{\mathrm{XSTO}}$ & 0.61 & 0.61 \\
\hline$\mu_{\mathrm{H}}$ & Maximum growth rate & $/ \mathrm{d}$ & 2.4 & 2.6 \\
\hline $\mathrm{k}_{\mathrm{h}}$ & Hydrolysis rate constant & $\mathrm{gCOD}_{\mathrm{XS}} / \mathrm{gCOD}_{\mathrm{XH}}$ & 3.03 & 3.03 \\
\hline $\mathrm{K}_{\mathrm{S}}$ & Saturation constant for $\mathrm{S}_{\mathrm{S}} / \mathrm{m}^{3}$ & 2.31 & 2.31 \\
\hline $\mathrm{K}_{\mathrm{X}}$ & Saturation constant. for particulate COD & $\mathrm{gCOD}_{\mathrm{SS}}$ & 1 & 1 \\
\hline $\mathrm{K}_{\mathrm{NH}}$ & Saturation constant for ammonium $\mathrm{g}_{\mathrm{NH}}$ & $\mathrm{gN}_{\mathrm{XS}} / \mathrm{gCOD}_{\mathrm{XH}}$ & 0.00107 & 0.00107 \\
\hline $\mathrm{K}_{\mathrm{O}}$ & Saturation constant for oxygen & $\mathrm{gO}_{2} / \mathrm{m}^{3}$ & 0.0233 & 0.0233 \\
\hline $\mathrm{K}_{\mathrm{A} \_}$ & Oxygen saturation constant for autotrophs & $\mathrm{gO}_{2} / \mathrm{m}^{3}$ & 0.5 & 0.8 \\
\hline $\mathrm{K}_{\mathrm{A} \_\mathrm{NH}}$ & Ammonium saturation constant for autotrophs & ${\mathrm{gN} / \mathrm{m}^{3}}$ & 2 \\
\hline
\end{tabular}


Figure 6

Simulation of effluent COD for the year 2006 (after the calibration)

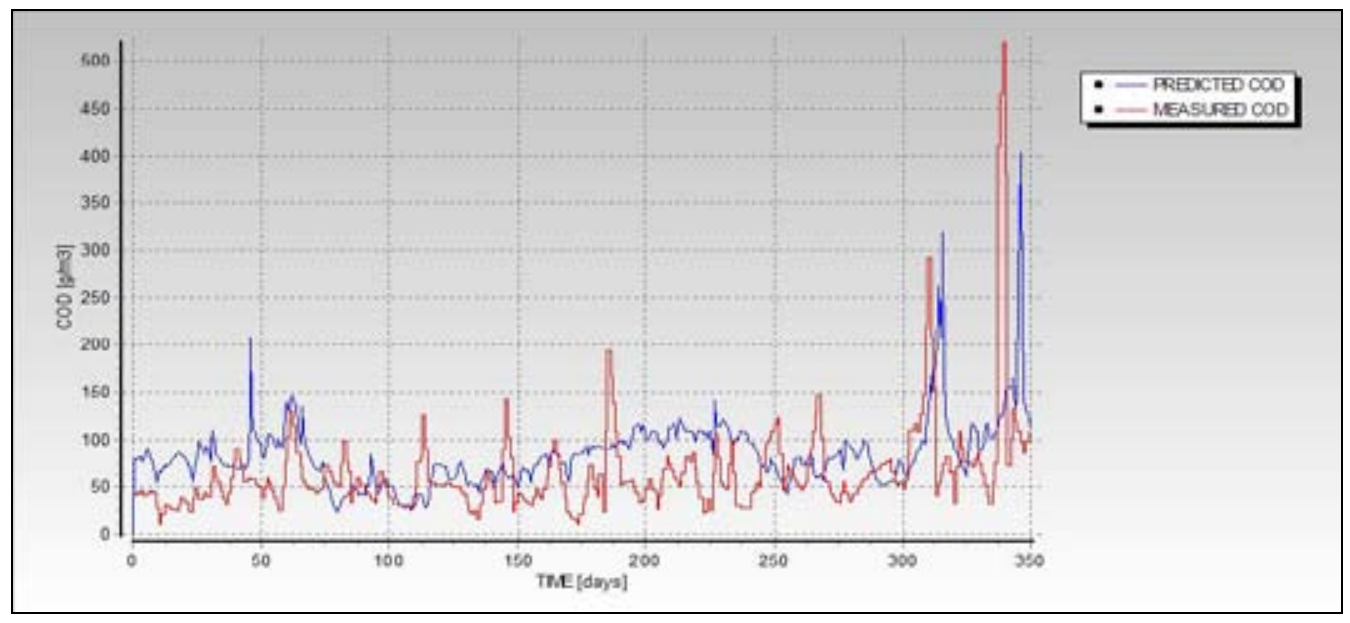

Figure 7

Effluent COD simulation after calibration for the year 2007

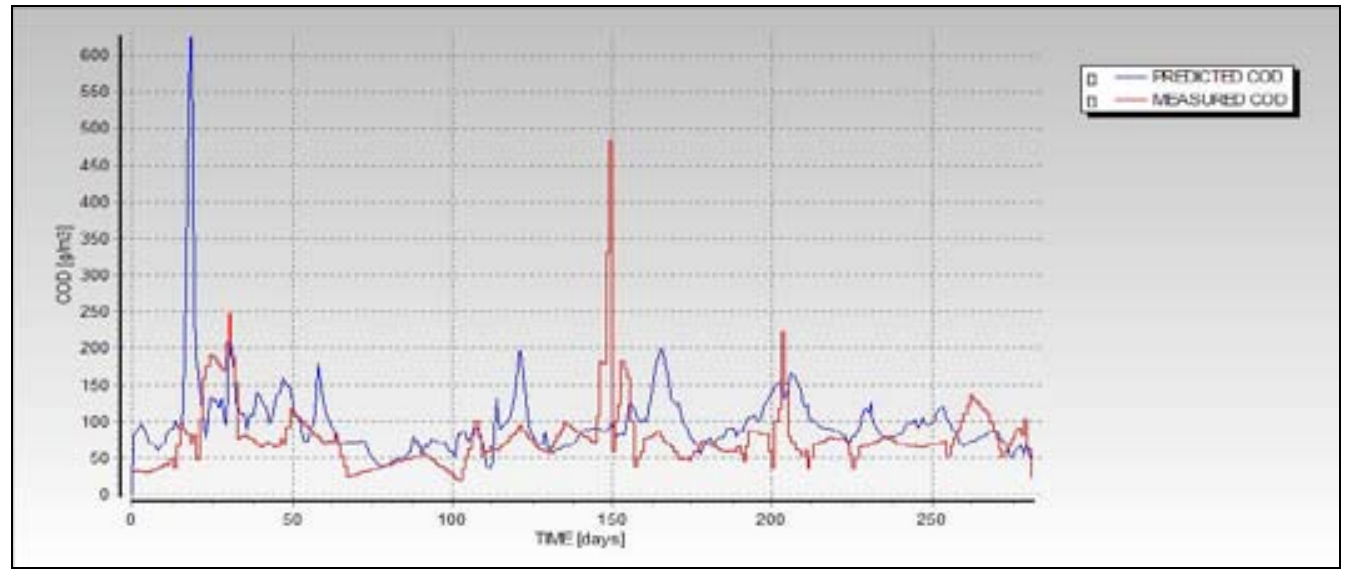

a lot of adjusting for the model to fit the plant data, then this implies reliable parameters. The extent to which the model fits the plant data with the available modelling information will also give a measure of how adequate the available information is for the purpose of modelling.

The heterotrophic yield coefficient $Y_{H}$, the hydrolysis rate constant $\mathrm{k}_{\mathrm{h}}$, the saturation constant of readily biodegradable substrate $\mathrm{K}_{\mathrm{S}}$ the saturation constant for particulate COD K , the saturation constant for particulate organics $\mathrm{K}_{\mathrm{NH}}$, and the saturation constant of oxygen $\mathrm{K}_{\mathrm{O}}$ remained unchanged during the calibration process, indicating that the obtained values were reliable.

The maximum growth rate for heterotrophic biomass $\mu_{\mathrm{H}}$ was adjusted from $2.4 / \mathrm{d}$ to $2.6 / \mathrm{d}$. The oxygen saturation constant for autotrophs $\mathrm{K}_{\mathrm{A}_{\mathrm{O}}}$ was adjusted from 0.5 to $0.8 \mathrm{gO}_{2} / \mathrm{m}^{3}$ and the ammonium saturation constant $\mathrm{K}_{\mathrm{A} \mathrm{NH}}$ was adjusted from 1 to $2 \mathrm{gN} / \mathrm{m}^{3}$. The initial values of the 2 saturation constants $\left(\mathrm{K}_{\mathrm{A}_{-} \mathrm{O}}\right.$ and $\left.\mathrm{K}_{\mathrm{A}_{-} \mathrm{NH}}\right)$ were literature values, i.e. not determined in the laboratory tests. The adjustment of these values indicates that experiments need to be carried out to determine them. The simulated effluent COD for the year 2006 after adjusting the model parameters is shown in Fig. 6 .

At this stage the model for the Mariannridge WWTP predicts trends of the effluent COD and the concentration; however, it does not follow all the sharp fluctuations that occur in the measured variables. Since the data were taken from routine plant records, it is not known how accurate the extreme values may be. Gaps in the measured data also affect the comparison.

\section{Model validation}

After dynamic calibration, validation of the model was carried out using historical data for the year 2007. Validation gives an indication of how well the model can simulate the treatment plant after the calibration effort. Figure 6 shows that the calibrated model can simulate the trend and fluctuations of the effluent COD concentration.

During the early stages of the simulation, the model indicates a noticeably high peak far from the measured value. This peak is due to a high COD value in the input file based on the measured influent COD. There is no way of being certain whether such individual discrepancies are due to problems with sampling and measurement, or with shortcomings in the model. The measured effluent COD does not indicate the peak, only the model shows how the high influent COD reflects in the effluent COD. For the rest of the simulation the model estimates the trends satisfactorily even though the peaks during fluctuations turn out to be higher.

\section{Conclusion}

The procedure for the development of a baseline model for a WWTP receiving a significant proportion of industrial effluent, based on a combination of laboratory tests and plant operating data was presented. The information used for the model was based on wastewater characterisation, sludge composition analysis and stoichiometric and kinetic parameters based on respirometric laboratory tests on wastewater and activated sludge. The wastewater characterisation based on the experi- 
ments carried out was satisfactory. Slight adjustments of the decay rate constant for heterotrophic biomass, and the maximum growth rate of the heterotrophic biomass which had been experimentally determined were made to improve the model, while the other 4 experimentally determined parameters retained their experimental values in the plant indicating that the experiment was reliable as a source of modelling information.

During dynamic calibration, the model parameters relevant for short-term predictions include the specific growth rates of heterotrophic and autotrophic biomass, $\mu_{\mathrm{H}}$ and $\mu_{\mathrm{A}}$ respectively as well as the saturation coefficients for readily biodegradable substrate, ammonia and oxygen for both heterotrophic and autotrophic organisms. These results indicate that determining the model parameters only for heterotrophic biomass is not sufficient. There is need to carry out experiments to determine model parameters related to the activity of autotrophic biomass.

The combination of laboratory tests, historical data from the municipal laboratory and modelling of experiments the laboratory tests makes up a methodology for developing a simulation model which can be a significant source of information for municipal policies in wastewater management.

\section{Acknowledgements}

This paper is based on a paper presented at the Water Institute of Southern Africa (WISA) Conference 2008, Sun City, South Africa. The authors would like to thank the Water Research Commission (WRC) and eThekwini Municipality of South Africa for supporting this research through funding, providing information and laboratory services.

\section{References}

MOSTforWATER (2004) WEST MSL Reference Guide. HEMMIS http://www.hemmis.be/EN/index.php HEMMIS transferred all the water quality modelling consultancy and related software WEST(R) to its daughter company MOSTforWATER URL:http:// www.mostforwater.com/EN/index.php.

BORTONE G, CHECH JS, GERMIRLI F, BIANCHI R and TILCHE A (1994) Experimental approaches for the characterisation of a nitrification/denitrification process on industrial wastewater. Proc. $1^{\text {st }}$ Int. Spec. Conf. on Micro-Organisms in Activated Sludge and Biofilm Processes. 27-28 September 1994, Paris, France. 129-136.

DOLD PL, EKAMA GA and MARAIS GvR (1980) A general model for the activated sludge process. Prog. Water Technol. 12 (6) 47-77.

DOLD PL, BAGG WK and MARAIS GvR (1986) Measurement of Readily Biodegradable COD Fraction in Municipal Wastewater by Ultrafiltration. UCT Report No. W57. Univ. of Cape Town, Cape Town, South Africa.

EKAMA GA and MARAIS GvR (1984) The nature of municipal wastewaters. In: WRC Report No. TT 16/84. Theory, Design and Operation of Nutrient Removal Activated Sludge Processes. Water Research Commission, Pretoria, Republic of South Africa.

GERNAEY KV, VAN LOOSDRECHT MCM, HENZE M, LIND MORTEN and JORGENSEN SB (2004) Activated sludge wastewater treatment plant modelling and simulation: State of the art. Environ. Modell. Software 19 (4) 763-783.
GRIJSPEERDT K, VANROLLEGHEM P and VERSTRAETE W (1995) Selection of one-dimensional sedimentation: Models for one-line use. Water Sci. Technol. 31 (2) 193-204.

GUJER W, HENZE M, MINO T and VAN LOOSDRECHT MCM (1999) Activated Sludge Model No. 3, IAWQ Technical Report, IAWQ, England.

HENZE M, GRADY CPL, GUJER W, MARAIS GvR and MATSUO T (1987) Activated Sludge Model No.1. IAWPRC Scientific and Technical Report No.1, IAWPRC, London.

HENZE M, GUJER W, MINO T, MATSUO T, WENTZEL MC and MARAIS GvR (1995) Activated Sludge Model No.2, IAWQ Scientific and Technical Report No.3, IAWQ, England.

HENZE M, GUJER W, MINO T, MATSUO T, WENZTEL MC, MARAIS GvR and VAN LOOSDRECHT MCM (1999) Outline of Activated Sludge Model No. 2d. Water Sci. Technol. 39 (1) 165-182.

HENZE M, GUJER W, MINO T and VAN LOOSDRECHT MCM (2000) Activated Sludge Models ASM1, ASM2, ASM2d and ASM3. IWA Scientific and Technical Report No.9, IWA Publishing, London, UK.

HVITVED-JACOBSEN (2002) Sewer Processes - Microbial and Chemical Process Engineering of Sewer Networks ( $1^{\text {st }}$ edn.) CRC Press, Florida, USA.

LANGERGRABER G, RIEGER L and WINKLER S (2004) A guideline for simulation studies of wastewater treatment plants. Water Sci. Technol. 50 131-138.

LESOUEF A, PAYRAUDEAU M, ROGALLA F and KLEIBER B (1992) Optimizing nitrogen removal reactor configurations by on-site calibration of the IAWPRC activated sludge model. Water Sci. Technol. 25 (6) 105-123.

LAGARDE F, TUSSEAU-VUILLEMIN MH, LESSARD P, HÉDUIT A, DUTROP F and MOUCHEL JM (2003) Variability estimation of urban wastewater biodegradable fractions by respirometry. Water Res. 39 (19) 4768- 4778.

MAMAIS D, JENKINS D and PITT P (1993) A rapid physical-chemical method for the determination of readily biodegradable soluble COD in municipal wastewater. Water Res. 27 (1) 195-197.

PEDERSEN J and SINKJAER O (1992) Test of activated sludge models capabilities as a prognostic too on a pilot scale wastewater treatment plant. Water Sci. Technol. 25 (6) 185-194.

PETERSEN B (2002) Calibration, Identifiability and Optimal Experiential Design of Activated Sludge Models. Ph.D. Thesis. Ghent Univ., Belgium.

SIN G, VAN HULLE S, DE PAUW D, GRIENSVEN A and VANROLLEGHEM P (2005) A critical comparison of systematic calibration protocols for activated sludge models: A SWOT analysis. Water Res. 39 (12) 2459-2474.

SPÉRANDIO M and PAUL E (2000) Estimation of wastewater biodegradable COD fractions by combining respirometric experiments in various So/Xo ratios. Water Res. 34 (4) 1233-1246.

STANDARD METHODS (1995) Standard Methods for the Examination of Water and Wastewater (1 $19^{\text {th }}$ edn.). American Public Health Association, Washington DC, USA.

STOKES L, TAKAC I, WATSON B and WATTS JB (1993) Dynamic modelling of an ASP sewage works - A case study. Water Sci. Technol. 28 (11-12) 151-161.

TORRIJOS M, CERRO RM, CAPDEVILLE B, ZEGHAL S PAYRAUDEAU M and LESOUEF A (1994) Sequencing batch reactor: Tool for wastewater characterisation for the IWAPRC model. Water Sci. Technol. 29 (7) 81-90.

WENTZEL MC, MBEWE A and EKAMA GA (1995) Batch measurements of readily biodegradable COD and active organism concentration in municipal wastewater. Water SA 21 (2) 117-124. 